\title{
IMPACT OF PERENNIAL RYEGRASS SEEDING DENSITIES ON WEED EMERGENCE, GROWTH AND DEVELOPMENT
}

\author{
S.S. SEEFELDT and M.L. ARMSTRONG \\ AgResearch, Ruakura Research Centre, Private Bag 3123, Hamilton
}

\begin{abstract}
Research was conducted to determine the effect of perennial ryegrass (Lolium perenne) sowing density on weed growth and development. In glasshouse and field experiments, perennial ryegrass was sown at rates of $0,5,10,20,40$ and $80 \mathrm{~kg} / \mathrm{ha}$, with $5 \mathrm{~kg} / \mathrm{hao}$ white clover (Trifolium repens). With increasing seeding density, perennial ryegrass enhanced its competitiveness against all five of the weeds studied, viz. nodding thistle (Carduus nutans), Californian thistle (Cirsium arvense), Scotch thistle (Cirsium vulgare), ragwort (Senecio jacobaea) and hedge mustard (Sisymbrium officinale). In both trials, increases in the perennial ryegrass seeding density did not reduce weed emergence. However, as perennial ryegrass density increased, weed biomass decreased and time to flowering increased.

Keywords: sowing density, competition, Lolium perenne, pasture resowing, weed growth.
\end{abstract}

\section{INTRODUCTION}

As in many countries, in New Zealand there is interest in reducing pesticide use and also increasing interest in organic farming. Herbicides are the most commonly used pesticide accounting for $68 \%$ of the total active ingredient applied in New Zealand (Holland and Rahman 1999). Thus any attempt at reducing the amount of pesticides must address the usage of herbicides. Pastures are particularly sensitive to weed infestation when they are being established and herbicides are frequently recommended to control them both pre- and post-planting (Rahman et al. 1993). The recommended sowing rate for perennial ryegrass (Lolium perenne) is 10 to $12 \mathrm{~kg} \mathrm{seed} /$ ha when herbicides and direct drilling are used and 15 to $20 \mathrm{~kg}$ seed/ha when tillage is used for seed bed preparation (Clough and Hay 1993).

Perennial ryegrass grows rapidly in cool conditions and is very competitive against other plant species (Fraser and Milne 1993). Although much work has been conducted on increasing the competitiveness of crops against weeds, very little of the work has been conducted in pastures. One method to increase the competitiveness of a crop is to increase the planting density (Cousens 1985). Early studies documented that sowing higher rates of perennial ryegrass resulted in reduced weeds (Cullen and Meeklah 1959) and that without competition from pasture nodding thistle had higher survival rates and behaved as a winter annual (Edmonds and Popay 1983). In New Zealand pasture systems, it may be economically beneficial to replace the cost of herbicides and their application(s) with the cost of additional perennial ryegrass seed. An increase in seeding density may achieve acceptable levels of weed control while increasing early pasture productivity. These benefits may be more pronounced in organic systems as such products attract a premium price, which will offset any reduced yields due to weeds. The objective of our research was to measure the impact of sowing increasing densities of perennial ryegrass on the germination and subsequent growth of five weed species. 


\section{Field experiment}

\section{MATERIALS AND METHODS}

A field experiment was established at the Ruakura Research Centre in a field that had been in kale (Brassica oleracea) for one year. The site was ploughed and harrowed before seeding and rolled after seeding. The treatments were perennial ryegrass (cv. Bronsyn) sown at rates of $0,5,10,20,40$ and $80 \mathrm{~kg} / \mathrm{ha}$, all with $5 \mathrm{~kg} / \mathrm{haof}$ white clover (50/50 mix of cv. Sustain and Aran). All treatments were sown by hand and seeds were raked in. There was also an unplanted control with no perennial ryegrass or white clover, to measure volunteer weeds. Plots were $3 \times 7 \mathrm{~m}$ and in each plot seven strips of three $0.25 \times 0.25 \mathrm{~m}$ subplots. Each subplot in a strip was planted with 100 seed of a weed species on 14 April 1999. The weed species planted were nodding thistle, Californian thistle, Scotch thistle, ragwort and hedge mustard.Emergence of the weed seeds was determined by counting plants on 31 May 1999 (47 days after planting, DAP). At that time the weeds under study were thinned to three plants and dry weights determined (first thinning). Other weeds were also removed at that time and their dry weights determined. When the remaining three weeds of a species were beginning to compete with each other, they were thinned by removing the largest and smallest plants and their dry weights determined (second thinning - nine months after planting). When the single remaining plant began to flower, it was removed, the date recorded and its dry weight determined. Sheep grazed the plots on 16 July, 11 September and 10 November 1999. The experiment was set up in a randomised complete block design with four replicates and a three-subplot strip for each weed species was randomised in the plots.

\section{Glasshouse experiment}

Polystyrene trays $(540 \times 340 \times 80 \mathrm{~mm})$ were filled with Horotiu silt loam soil. Perennial ryegrass (cv. Bronsyn) was sown into the trays and lightly worked into the soil by hand at rates of $0,5,10,20,40,80,160$ and $320 \mathrm{~kg} / \mathrm{ha}$, with $5 \mathrm{~kg} / \mathrm{ha}$ of white clover (50/50 mix of cv. Sustain and Aran) on 7 September 1999. There was also a control treatment with no perennial ryegrass or white clover. On the same day, into a $0.25 \times 0.25 \mathrm{~m}$ area at least $60 \mathrm{~mm}$ from the side of the tray (to reduce edge effect), each tray was infested with a single weed species. Fifty seeds of Scotch thistle and nodding thistle and 100 seeds of Californian thistle, ragwort, and hedge mustard were planted. After 50 days the trays were moved outside. Trays were watered as needed and fertilised weekly with a standard nutrient solution.

On 26 October 1999 (49 DAP) weed emergence was recorded and weeds thinned back to three per tray. Dry weight of the thinned plants was determined. When the remaining three plants of a weed species were beginning to compete with each other, they were thinned by removing the largest and smallest plants and their dry weights determined ( 4 months after planting). When the single remaining plant began to flower it was removed, the date recorded and its dry weight determined. On 28 October 1999 the perennial ryegrass and white clover plants were cut back to a $30 \mathrm{~mm}$ height with clippers to simulate grazing. This was repeated every 28 days with care being taken not to damage the weeds. The experiment was laid out in a randomised complete block design with four replicates. Trays within blocks were rotated every 7 days to minimise differences in glasshouse position. When the plants were moved outside the trays were randomised by treatment to facilitate watering, but after 8 March 2000 they were completely randomised.

\section{Analysis}

Emergence data and dry weight data were analysed by ANOVA. Perennial ryegrass densities were log transformed for both thinnings. In the second thinning plant weights were also log transformed to reduce variation, especially for the low ryegrass densities. Regression analysis was used to describe the weed response to increasing perennial ryegrass densities. A chi-square test was used to determine the affect of increasing perennial ryegrass density on Californian thistle and hedge mustard plant mortality and size. 
TABLE 1: Effect of sowing rates of perennial ryegrass on percent emergence of five weed species under field and glasshouse conditions.

\begin{tabular}{|c|c|c|c|c|c|c|c|c|c|c|}
\hline \multirow{3}{*}{$\begin{array}{l}\text { Density } \\
\text { ryegrass }\end{array}$} & \multirow{3}{*}{$\begin{array}{l}\mathrm{kg} / \mathrm{ha} \\
\text { white } \\
\text { clover }\end{array}$} & \multicolumn{9}{|c|}{ Weed species / Location } \\
\hline & & \multicolumn{2}{|c|}{$\begin{array}{c}\text { Californian } \\
\text { thistle }\end{array}$} & \multicolumn{2}{|c|}{$\begin{array}{l}\text { hedge } \\
\text { mustard }\end{array}$} & \multicolumn{2}{|c|}{$\begin{array}{l}\text { nodding } \\
\text { thistle }\end{array}$} & \multirow{2}{*}{$\begin{array}{c}\text { ragwort } \\
\text { F }\end{array}$} & \multicolumn{2}{|c|}{$\begin{array}{l}\text { Scotch } \\
\text { thistle }\end{array}$} \\
\hline & & $\mathrm{F}^{1}$ & $\mathrm{G}$ & $\mathrm{F}$ & $\mathrm{G}$ & $\mathrm{F}$ & $\mathrm{G}$ & & $\mathrm{F}$ & $\mathrm{G}$ \\
\hline 0 & 0 & 13 & 43 & 13 & 48 & 21 & 36 & 1.5 & 12 & 44 \\
\hline 0 & 5 & 17 & 36 & 13 & 54 & 19 & 38 & 4.5 & 13 & 44 \\
\hline 5 & 5 & 13 & 42 & 11 & 51 & 17 & 38 & 5.5 & 11 & 34 \\
\hline 10 & 5 & 15 & 29 & 10 & 39 & 19 & 34 & 2.5 & 11 & 38 \\
\hline 20 & 5 & 13 & 41 & 10 & 50 & 18 & 30 & 3.3 & 12 & 36 \\
\hline 40 & 5 & 9 & 41 & 7 & 47 & 16 & 38 & 3.0 & 9 & 38 \\
\hline 80 & 5 & 9 & 35 & 7 & 44 & 12 & 22 & 4.8 & 7 & 34 \\
\hline 160 & 5 & - & 36 & - & 44 & - & 34 & 4.3 & - & 40 \\
\hline 320 & 5 & - & 31 & - & 43 & - & 22 & 2.8 & - & 40 \\
\hline
\end{tabular}

${ }^{1}$ Abbreviations: $\mathrm{F}=$ field and $\mathrm{G}=$ glasshouse.

\section{Emergence}

\section{RESULTS}

Emergence was variable among the weed species both in the field and glasshouse (Table 1). However, in no case was there any effect of perennial ryegrass density on the rate of weed emergence. Ragwort emergence was very low in the glasshouse and there was no emergence at the field site. Californian thistle, nodding thistle, Scotch thistle and hedge mustard emergence was greatest at the glasshouse, probably due to the warmer temperatures, less predation on seed and excellent moisture conditions. First thinning

There were insufficient ragwort plants to analyse at the first thinning. Generally, for the remaining four weed species, increasing perennial ryegrass densities had a significant effect on reducing weed plant dry weight (Fig. 1 and Table 2). However, the different weed species responded quite differently to increasing perennial ryegrass density. Also, the rate of growth at the two sites was different with plants being larger in the field. The site differences were probably due to increased light in the field and tray size effects in the glasshouse. Hedge mustard was much more negatively affected by increases in perennial ryegrass density in the glasshouse than Californian thistle, nodding thistle and Scotch thistle. In the field, Californian thistle was similar in size to that in the glasshouse whereas hedge mustard, nodding thistle and Scotch thistle were larger, particularly at the lower perennial ryegrass densities. The field grown

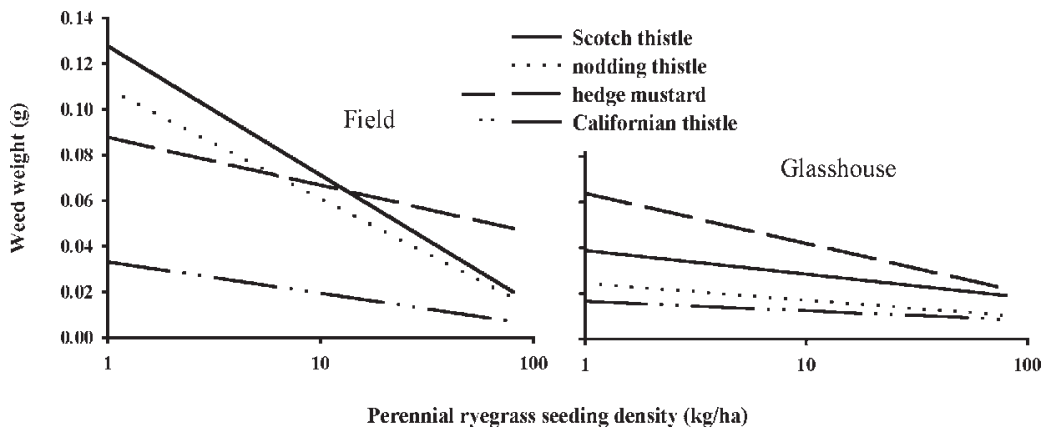

FIGURE 1: Effect of perennial ryegrass on weed growth seven weeks after sowing under field and glasshouse conditions. 
nodding thistle and Scotch thistle was much more sensitive to increases in perennial ryegrass density, as indicated by the steeper slope of the responses, than found in the glasshouse. Hedge mustard response to perennial ryegrass density in both the field and glasshouse was similar with the slopes being parallel (Fig. 1).

\section{Second thinning}

At the field site Californian thistle and hedge mustard mortality was large with most of the plants being lost to grazing, trampling, disease or, in the case of Californian thistle, cold temperatures during the winter. A chi-square test indicated that as perennial ryegrass density increased mortality increased and the size of the remaining Californian thistle and hedge mustard plants decreased. For the remaining weed plants at the field site and for the weeds at the glasshouse, weed size was reduced as perennial ryegrass density increased (Fig. 2 and Table 2). Scotch thistle size reductions were the same at both the glasshouse and the field site, whereas nodding thistle at the field site was more sensitive to increases in perennial ryegrass density. Californian thistle and hedge mustard were affected in a similar way by increases in perennial ryegrass density.

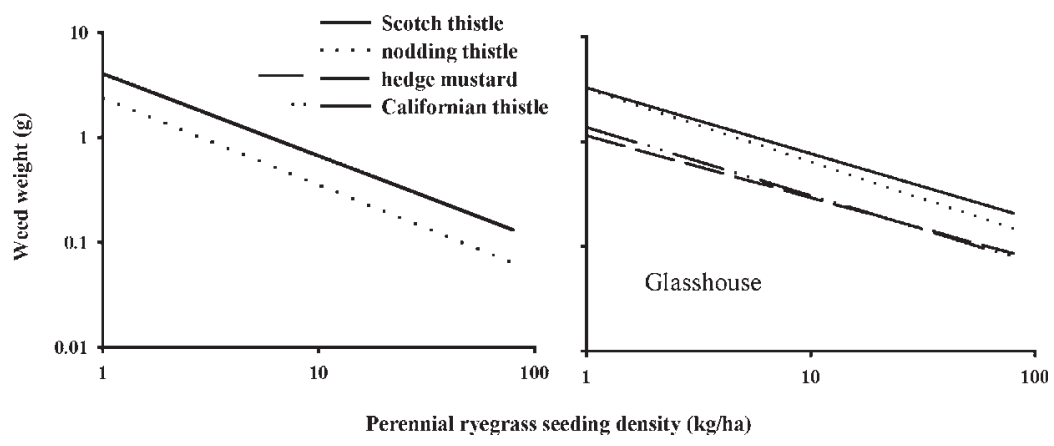

FIGURE 2: Effect of perennial ryegrass on weed growth after sowing under field and glasshouse conditions.

TABLE 2: Response of five weed species to increases in perennial ryegrass sowing densities over time under field and glasshouse conditions.

\begin{tabular}{|c|c|c|c|c|}
\hline Thinning & Species & Location & Line equation & $\mathrm{R}^{2}$ \\
\hline \multirow[t]{8}{*}{ first } & \multirow[t]{2}{*}{ Scotch thistle } & field & $\mathrm{y}=-0.0248(\operatorname{Ln}(\mathrm{x}))+0.1287$ & 0.95 \\
\hline & & glasshouse & $\mathrm{y}=-0.0045(\operatorname{Ln}(\mathrm{x}))+0.0387$ & 0.75 \\
\hline & \multirow[t]{2}{*}{ nodding thistle } & field & $\mathrm{y}=-0.0209(\operatorname{Ln}(\mathrm{x}))+0.1089$ & 0.97 \\
\hline & & glasshouse & $\mathrm{y}=-0.0032(\operatorname{Ln}(\mathrm{x}))+0.0243$ & 0.78 \\
\hline & \multirow[t]{2}{*}{ hedge mustard } & field & $\mathrm{y}=-0.0091(\operatorname{Ln}(\mathrm{x}))+0.0877$ & 0.21 \\
\hline & & glasshouse & $\mathrm{y}=-0.0095(\operatorname{Ln}(\mathrm{x}))+0.0637$ & 0.95 \\
\hline & \multirow[t]{2}{*}{ Californian thistle } & field & $\mathrm{y}=-0.006(\operatorname{Ln}(\mathrm{x}))+0.0332$ & 0.86 \\
\hline & & glasshouse & $\mathrm{y}=-0.0018(\operatorname{Ln}(\mathrm{x}))+0.0164$ & 0.84 \\
\hline \multirow[t]{6}{*}{ second } & \multirow[t]{2}{*}{ Scotch thistle } & field & $\mathrm{y}=4.0705 \mathrm{x}^{-0.7845}$ & 0.81 \\
\hline & & glasshouse & $y=3.2777 x^{-0.6289}$ & 0.99 \\
\hline & \multirow[t]{2}{*}{ nodding thistle } & field & $\mathrm{y}=2.3666 \mathrm{x}^{-0.8272}$ & 0.82 \\
\hline & & glasshouse & $y=3.1913 x^{-0.7}$ & 0.95 \\
\hline & hedge mustard & glasshouse & $\mathrm{y}=1.1343 \mathrm{x}^{-0.5901}$ & 0.94 \\
\hline & Californian thistle & glasshouse & $\mathrm{y}=1.3666 \mathrm{x}^{-0.6496}$ & 0.90 \\
\hline
\end{tabular}




\section{Flowering}

Hedge mustard generally flowered at the same date regardless of perennial ryegrass density. At the glasshouse nodding thistle and Scotch thistle had not flowered by early May whereas in the field half the nodding thistle and Scotch thistle in the noperennial ryegrass treatments had flowered. By this date only one Californian thistle had flowered in the glasshouse in the no plant control.

\section{DISCUSSION}

In these experiments we did not detect any differences in weed emergence due to perennial ryegrass planting density (Table 1). This is not surprising, as emerging grasses cause minimal interference to nearby plants. However, within 50 days of planting, the perennial ryegrass plants had begun to exert a significant amount of competitive pressure on adjacent weeds (Fig. 1). In all cases the weeds were shaded by the taller perennial ryegrass and the growth rate of the weeds was reduced as a function of the perennial ryegrass density. Hedge mustard was least affected during its early growth. Perhaps its leaf shape allowed it to penetrate the perennial ryegrass sward and its structure became more erect in response to crowding. In contrast, surrounding perennial ryegrass plants easily constricted the nodding thistle and Scotch thistle leaves which could not change their prostrate growth habit.

Small differences in plant size early in life translated into much larger differences later in the year. Nodding thistle and Scotch thistle growing with lower densities of perennial ryegrass were more than an order of magnitude larger than those growing in higher perennial ryegrass densities (Fig. 2). Californian thistle and hedge mustard in the glasshouse experiment, where grazing was done artificially, were less sensitive to increases in perennial ryegrass density, but the effect was still very large. However, in the field, these smaller plants were mostly eliminated during grazing. With no competition from plants other than clover, nodding thistle and Scotch thistle in the field grew large enough to flower. With the inclusion of ryegrass these plants were forced into a biennial life cycle, which agrees with findings of Edmonds and Popay (1983). In the glasshouse at the highest two densities almost $40 \%$ of the nodding thistle and Scotch thistle died within the first 6 months of the experiment.

From these results it is clear that increasing the planting density of perennial ryegrass will, from early after planting, reduce the biomass of the weed population if not the initial numbers of weeds. This difference in weed biomass will be magnified as the growing season progresses. The smaller weeds found in the higher density plots are more susceptible to elimination due to trampling, grazing and disease. In addition their time to flowering is lengthened or if the flowering is determinate, such as with hedge mustard, seed production will be reduced due to the smaller size of the plant.

A determination of the economics of replacing the cost of herbicides with the cost of additional perennial ryegrass seed can not be extrapolated from these experiments. The field site could not be grazed by treatment although the high-density treatments, which produced denser pasture, were ready to be grazed a week or more before the lower density treatments. Due to the limitations of grazing at a timetable that matched the lower density treatments, we were not able to determine all the potential early benefits of sowing higher rates of perennial ryegrass. Certainly from these results, it is clear that increasing the sowing rate of ryegrass will decrease the size of the weed population. Because we hand sowed perennial ryegrass in these experiments, we did not have the bare row spaces that typically occur when drilling in a new pasture. These row spaces represent sizeable low ryegrass density areas, which permit the rapid growth of weeds, that farmers are forced to spray out. Equipment which would more randomly spread seed, such as seed boxes with a Cambridge roller, may be effective in reducing the impact of weeds.

\section{ACKNOWLEDGEMENTS}

Funding for this project was provided by the New Zealand Foundation for Research, Science and Technology. The authors would like to thank Jon Stephens and Michael Trolove for their technical assistance and John Waller for his help with statistical analyses. 


\section{REFERENCES}

Clough, T.J. and Hay, R.J.M., 1993. Pasture species and cultivars. Pp 25-33In: Pasture Renovation Manual, R.P. Pottinger, P.M.S. Lane and J.R. Wilkens (Eds); AgResearch, Hamilton..

Cousens, R., 1985. An empirical model relating crop yield to weed and crop density and a statistical comparison with other models. J. Agric. Sci. 105:513-521.

Cullen, N.A. and Meeklah, F.A.H., 1959. Seeding rates and weedkillers in pasture weed control. Proc. 12th N.Z. Weed Cont. Conf. 12:54-58.

Edmonds, D.K. and Popay, A.I., 1983. Effect of pasture competition on the survival and flowering of nodding thistle. Proc. 36th N.Z. Weed and Pest Cont. Conf. 36:89-92.

Fraser, T. and Milne, G., 1993. Dryland pasture species and cultivars Pp 124-133 In: Pasture Renovation Manual, R.P. Pottinger, P.M.S. Lane and J.R. Wilkens (Eds); AgResearch, Hamilton. Pages .

Holland, P. T. and Rahman, A., 1999. Review of trends in agricultural pesticide use in New Zealand. MAF Policy Technical Paper 99/11. Ministry of Agriculture and Forestry, Wellington. $53 \mathrm{pp}$.

Rahman, A., James, T.K. and Bourdôt, G., 1993. Weed Control. Pp 78-86In: Pasture Renovation Manual, R.P. Pottinger, P.M.S. Lane and J.R. Wilkens (Eds); AgResearch, Hamilton. 